\title{
Sahara deserts ensure sustainable energy security of MENA countries and Europe
}

\author{
S. Flazi ${ }^{1}$ and A. Boudghene Stambouli ${ }^{2}$ \\ ${ }^{1}$ Department of Electrical Engineering, ${ }^{2}$ Department of Electronics \\ University of Sciences and Technology of Oran Mohamed Boudiaf (USTO-MB) \\ E-mail: flazis@yahoo.fr
}

\begin{abstract}
In this article, a particular attention is being given to first the Middle East \& north Africa Deserts (MENA) in terms of solar potential capability in that it could capture enough solar energy to meet the entire world's energy needs using Very Large Scale- Photovoltaic (VLS-PV) system, second to its possibility of attracting inhabitant for accessing to a good quality life, agriculture and energy infrastructure, third to its Sand or Silicon (Si) reserves which is more than the needs to manufacture Photovoltaic (PV) cells for all the suitable area of MENA deserts.
\end{abstract}

\section{Keywords}

Photovoltaic, Solar energy, Sustainable development, Sahara, Sand.

\section{Introduction}

Of all the RE sources now being fiercely debated, solar generation seems to be custom-tailored for Middle East \& north Africa (MENA ) countries being endowed with large reserves of solar energy source . It is clean, efficient, freely available and now becoming more affordable. With almost 365 days of radiant sunshine a year, MENA Deserts has the potential to be one of the major contributors in solar energy and become a role model to other region in the world.

With a total area of 11.65 million $\mathrm{km}^{2}$, the (MENA) deserts extends over 27 countries being Bahrain, Qatar, Oman, Kuwait, Lebanon, Palestine [Israel, West Bank (Cisjordanie) and Gaza], Jordan, United Arab Emirates, Syria, Yemen, Saudi Arabia, Iraq, Iran, Egypt, Libya, Tunisia, Algeria, Morocco, Western sahara, Mauritania, Mali, Niger, Chad, Sudan and South Sudan. It is hoped that energy potential using VLS-PV system would be sufficient to meet MENA countries and Europe countries energy needs in the future at the end of oil. Sharing this energy should become the engine for sustainable energy which guarantees a global future for all populations, the unbreakable link between the countries for a lasting peaceful world.

\section{MENA deserts irradiation compared to world energies}

Total annual irradiation for all world deserts (31 deserts of 19 million $\mathrm{km}^{2}$ ), was calculated [1-3]. A summary of calculated results is depicted in Tables 1 and 2. The first one concerns the annual irradiation at different world deserts grouped by region and the second one is about the annual irradiation at the MENA deserts. It can be seen easily that the MENA deserts has a $65 \%$ share of the total irradiation of world deserts which is higher the primary energy consumption of the world in 2011 (12275 Mtoe [4]) the MENA deserts annual irradiation (2262132 Mtoe/y) is more than 184 times higher.

\section{MENA deserts solar net energy potential using VLS-PV}

\subsection{Suitable area for VLS-PV system}

The deserts offer contrasting landscapes (Figure 1): sand dunes, oasis, wades (dry beds of rivers and streams), mountains, reg (composed of pebbles and gravel) and steppe. It is impossible to use the total area of the deserts for VLS-PV (Very Large Scale- Photovoltaic) system; the suitable area for this kind of systems is the regs and the steppes only.

Table 3 shows a rough calculation of the different areas of MENA deserts; it can be seen that the suitable area for VLS-PV is about $6956500 \mathrm{~km}^{2}$.

\subsection{The range of $V L S-P V$ system}

The size of a VLS- PV system may range from $10 \mathrm{MW}$ to 1 or several GW, consisting of one plant, or an aggregation of plural units [5]. Figure 2 shows a conceptual image of a one GW system [5,6 ], occupying $30 \mathrm{~km}^{2}(15 \mathrm{~km} \times 2 \mathrm{~km})$ of land, and taking into account, PV collectors, buffer plant, roods and transmission lines. 
Table 1: Annual irradiation in world deserts grouped by region

\begin{tabular}{|c|c|c|c|c|c|c|}
\hline \multicolumn{2}{|c|}{ WORLD REGION DESERTS } & \multirow{2}{*}{$\begin{array}{l}\begin{array}{l}\text { Area } \\
\left(\mathbf{k m}^{2}\right)\end{array} \\
8600000 \\
\end{array}$} & \multirow{2}{*}{$\begin{array}{r}\begin{array}{c}\text { Annual } \\
\text { irradiation } \\
(\mathbf{k W h} / \mathbf{m} \mathbf{2})\end{array} \\
2300\end{array}$} & \multirow{2}{*}{$\begin{array}{c}\begin{array}{c}\text { Total } \\
\text { annual } \\
\text { irradiation } \\
\text { (PWh) }\end{array} \\
19780\end{array}$} & \multirow{2}{*}{$\begin{array}{c}\begin{array}{c}\text { Total } \\
\text { annual } \\
\text { irradiation } \\
\text { (Mtoe) }\end{array} \\
1701080 \\
\end{array}$} & \multirow{2}{*}{$\begin{array}{c}\begin{array}{c}\text { share of } \\
\text { total } \\
\text { annual }\end{array} \\
\begin{array}{c}\text { irradiation } \\
(\%)\end{array} \\
48,79\end{array}$} \\
\hline \multirow{3}{*}{ 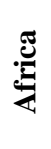 } & North Africa (Sahara) & & & & & \\
\hline & South Africa (2)* & 1040000 & 2313 & 2406 & 206916 & 5,94 \\
\hline & TOTAL AFRICA (3)* & 9640000 & 2301 & 22186 & 1907996 & 54,73 \\
\hline \multirow{3}{*}{$\frac{\sqrt{5}}{2}$} & Middle East (6)* & 3052400 & 2137 & 6524 & 561052 & 16,09 \\
\hline & Central Asia (5)* & 2420000 & 1661 & 4019 & 345634 & 9,91 \\
\hline & TOTAL ASIA (11)* & 5472400 & 1927 & 10543 & 906686 & 26,01 \\
\hline \multirow{2}{*}{ 舀 } & & & & & & \\
\hline & TOTAL AUSTRALIA (10)* & 1388743 & 2246 & 3119 & 268256 & 7,69 \\
\hline \multirow{3}{*}{ 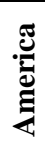 } & North America (5)* & 1664000 & 2188 & 3641 & 313126 & 8,98 \\
\hline & South America (2)* & 813000 & 1289 & 1048 & 90154 & 2,59 \\
\hline & TOTAL AMERICA (7)* & 2477000 & 1893 & 4689 & 403280 & 11,57 \\
\hline \multicolumn{2}{|c|}{$\begin{array}{l}\text { TOTAL WORLD DESERTS (31)* } \\
* \text { Deserts number }\end{array}$} & 18978143 & 2136 & 40537 & 3486218 & 100 \\
\hline
\end{tabular}

Table 2: Annual irradiation in MENA deserts

\begin{tabular}{|l|r|r|r|r|r|}
\hline North Africa (NA) & 8600000 & 2300 & 19780 & 1701080 & 49 \\
\hline Middle East (ME) & 3052400 & 2137 & 6524 & 561052 & 16 \\
\hline Middle East+North Africa= (MENA) & 11652400 & 2257 & 26304 & 2262132 & 65 \\
\hline
\end{tabular}
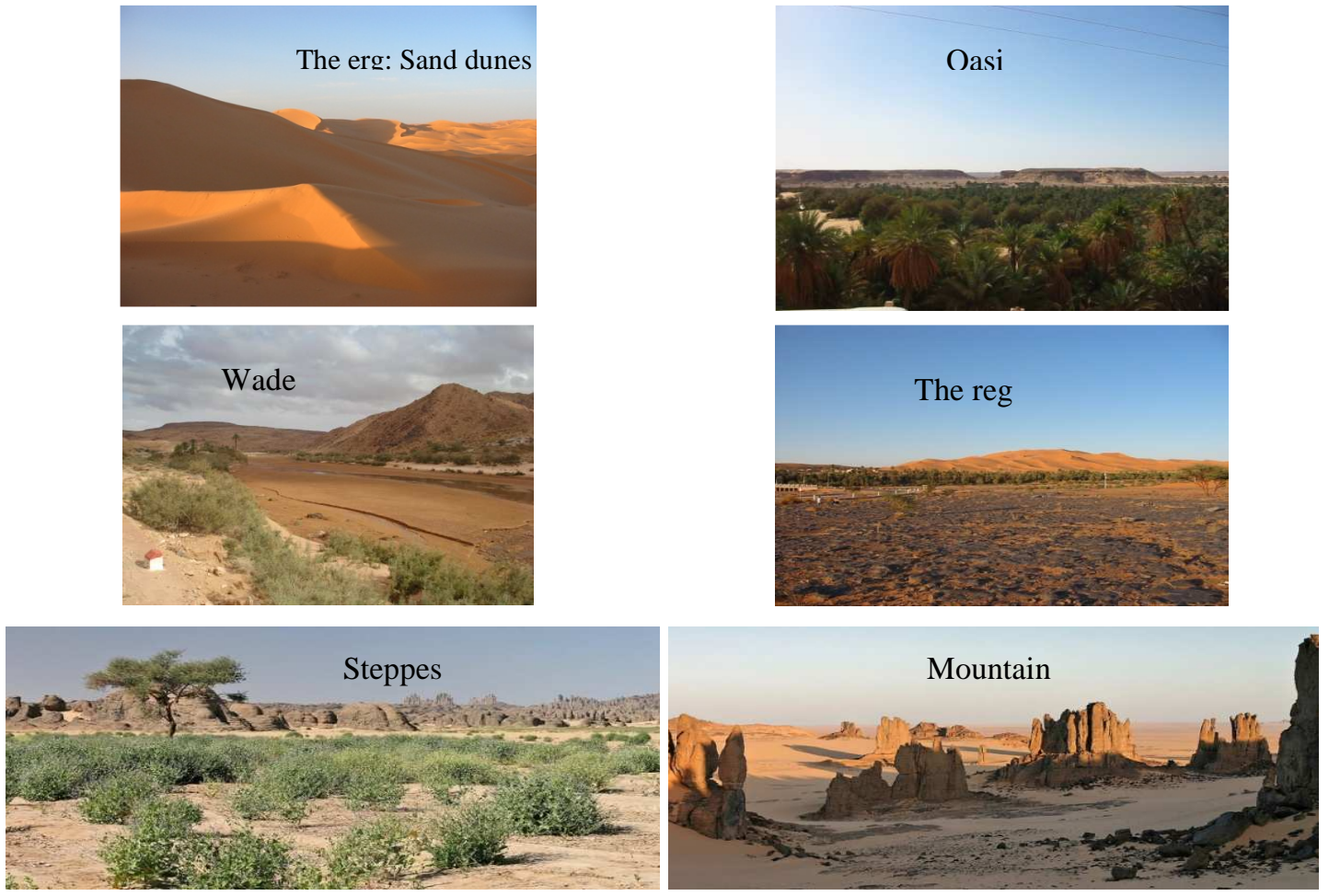

Figure 1: deserts contrasting landscapes

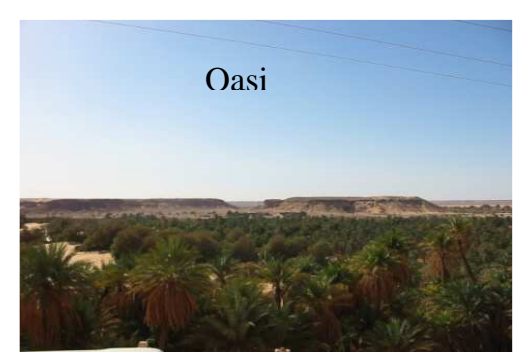

The reg

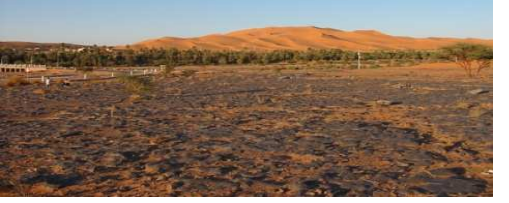

Mountain 
Table 3: different areas of MENA deserts

\begin{tabular}{|c|c|c|c|c|}
\hline $\begin{array}{c}\text { Total area } \\
\left(\mathrm{km}^{2}\right)\end{array}$ & $\begin{array}{c}\text { Sand dune } \\
\text { area }\left(\mathrm{km}^{2}\right) \\
20 \%\end{array}$ & $\begin{array}{c}\text { Oasis area } \\
\left(\mathrm{km}^{2}\right)\end{array}$ & $\begin{array}{c}\text { Mountain area } \\
\left(\mathrm{km}^{2}\right) 18 \%\end{array}$ & $\begin{array}{c}\text { Reg and Steppe } \\
\text { area }\left(\mathrm{km}^{2}\right)\end{array}$ \\
\hline 11652400 & 2330480 & 268000 & 2097432 & 6956488 \\
\hline
\end{tabular}
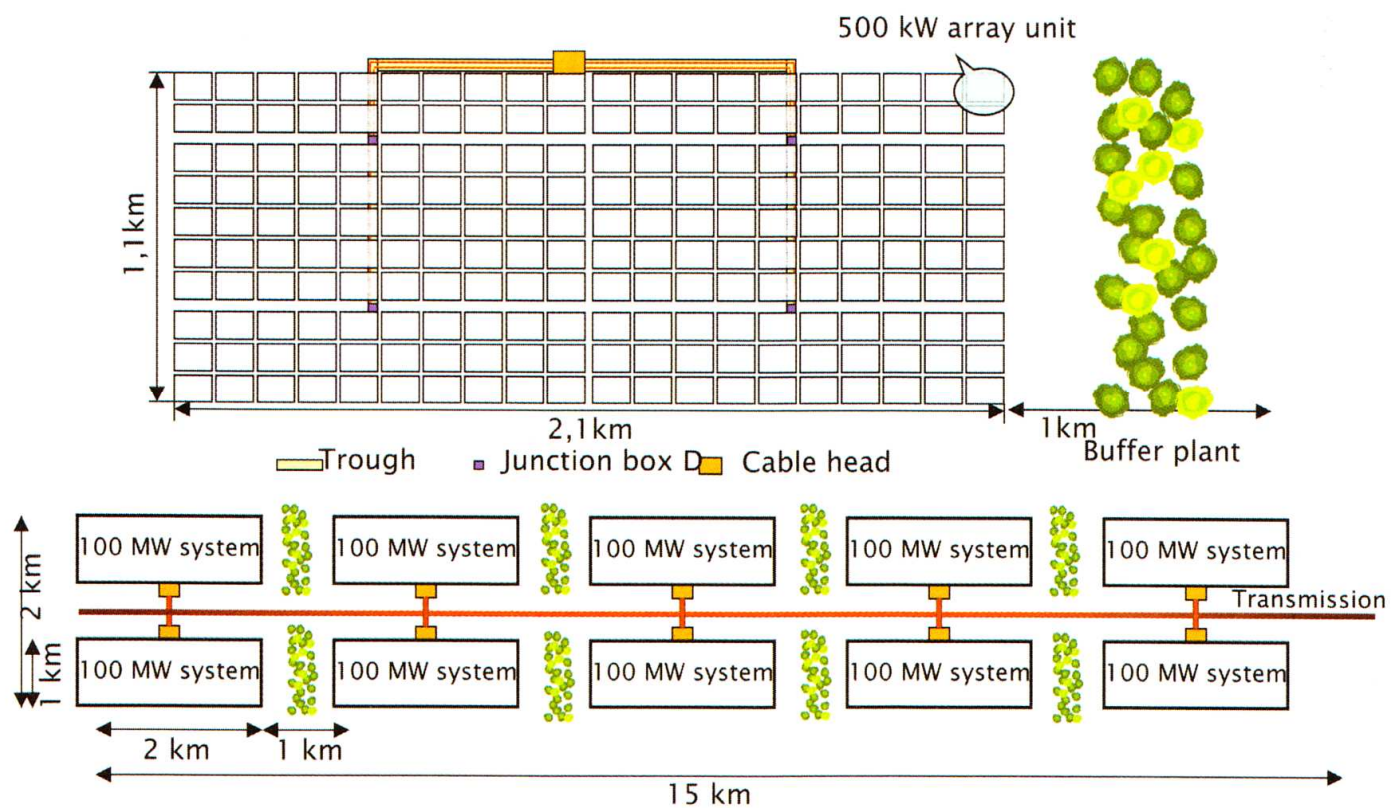

Figure 2: conceptual image of a one GW system [ 3,4 ].

\subsection{PV capacity and annual power generation}

Table 4 shows a rough calculation of PV capacity and annual power generation for all the suitable area of MENA deserts using VLS-PV based on a conceptual image of a one GW system of figure 2 .
A comparison with world primary energy consumption [2] allowed us to conclude that MENA solar net annual energy potential using VLS-PV with buffer plants and roads (31 538 Mtoe) is more than 2 times higher of world consumption in 2030 (15000 Mtoe).

Table 4: PV capacity and Annual energy generation for all the Suitable Deserts area of MENA

\begin{tabular}{|c|c|c|c|c|}
\hline $\begin{array}{c}\text { PV Capacity and Energy } \\
\text { generation using VLS- } \\
\text { PV system }\end{array}$ & $\begin{array}{c}\text { PV } \\
\text { capacity } \\
\text { (TW) }\end{array}$ & $\begin{array}{c}\text { Annual } \\
\text { generation } \\
\text { (PWh) }\end{array}$ & $\begin{array}{c}\text { Annual } \\
\text { generation } \\
\text { (Mtoe) }\end{array}$ & $\begin{array}{c}\text { Annual } \\
\text { generation to } \\
\text { gross annual } \\
\text { irradiation \% }\end{array}$ \\
\hline $\begin{array}{c}\text { Without buffer plant and } \\
\text { without road }\end{array}$ & $\mathbf{4 8 7}$ & $\mathbf{7 6 9}$ & $\mathbf{6 6} 163$ & $\mathbf{2 , 9 3}$ \\
\hline $\begin{array}{c}\text { Without buffer plant but with } \\
\text { road }\end{array}$ & $\mathbf{3 4 8}$ & $\mathbf{5 5 0}$ & $\mathbf{4 7 3 0 7}$ & $\mathbf{2 , 0 9}$ \\
\hline $\begin{array}{c}\text { With buffer plant and with } \\
\text { road }\end{array}$ & $\mathbf{2 3 2}$ & $\mathbf{3 6 7}$ & $\mathbf{3 1 ~ 5 3 8}$ & $\mathbf{1 , 3 9}$ \\
\hline
\end{tabular}

\section{What can we do by this area or this energy?}

Many purposes can be achieved in that:

- Clean energy production, using Very Large ScalePhotovoltaic system,

- Sustainable development of MENA countries,

- Clean energy production for export to Europe countries,

- Desert greening, cultivation \& repopulation:

\subsection{Clean energy production for sustainable} development of MENA countries

Table 5, 6 and 7 show calculation results of MENA countries population in 2030 and annual energy needs in 2030 (5toe/capita). It can be seen that the needed energy, of MENA countries, in 2030 will be about 4116 which amount the value of $13 \%$ of total MENA potential. 
Table 5: annual energy needs

for sustainable development of ME countries (2030)

\begin{tabular}{|l|r|r|r|r|r|}
\hline $\begin{array}{c}\text { Country (or dependent } \\
\text { territory) }\end{array}$ & Area (km2) & Population 2013 & $\begin{array}{l}\text { Growth } \\
\text { rate }\end{array}$ & $\begin{array}{c}\text { Population } \\
2030\end{array}$ & $\begin{array}{l}\text { annual } \\
\text { energy needs } \\
\text { (Mtoe) } \\
\text { 2030, }\end{array}$ \\
\hline Northern Cyprus & & & & & \\
\hline Cyprus & 9251 & 294906 & 1,08 & 353991 & 1,8 \\
\hline Bahrain & 741 & 1546000 & 7,36 & 5170494 & 25,9 \\
\hline Qatar & 11586 & 1941000 & 4,24 & 3931972 & 19,7 \\
\hline Oman & 3095 & 2950000 & 2,43 & 4436944 & 22,2 \\
\hline Kuwait & 17818 & 3852000 & 2,94 & 6304012 & 31,5 \\
\hline Lebanon & 104 & 4127000 & 1,58 & 5387335 & 26,9 \\
\hline Palestine * & 22574 & 12419000 & 2,16 & 18244944 & 91,2 \\
\hline Jordan & 89342 & 6517000 & 2,84 & 10490662 & 52,5 \\
\hline United Arab Emirates & 836 & 8659000 & 1,56 & 11265579 & 56,3 \\
\hline Syria & 185180 & 22269000 & 2,45 & 34351036 & 171,8 \\
\hline Yemen & 527968 & 25252000 & 2,96 & 41463013 & 207,3 \\
\hline Saudi Arabia & 2000000 & 30193000 & 3,41 & 53391167 & 267,0 \\
\hline Iraq & 438317 & 35404000 & 3,06 & 59099619 & 295,5 \\
\hline Turkey & 783562 & 76081000 & 1,21 & 93341427 & 466,7 \\
\hline Iran & 1648195 & 76789000 & 1,29 & 95484026 & 477,4 \\
\hline Total Asia & 5729318 & 307999000 & & 442362230 & 2211,9 \\
\hline
\end{tabular}

* (Israel+ West Bank + Gaza)

Table 6: annual energy needs

for sustainable development of NA countries (2030)

\begin{tabular}{|c|c|c|c|c|c|}
\hline Country & Area $(\mathrm{km} 2)$ & Population 2010 & $\begin{array}{l}\text { Growth } \\
\text { rate }\end{array}$ & $\begin{array}{l}\text { Population } \\
2030\end{array}$ & $\begin{array}{l}\text { annual } \\
\text { energy needs } \\
\text { (Mtoe) 2030, } \\
\text { (5toe/capita) }\end{array}$ \\
\hline Morocco & 458730 & 31951000 & 1,42 & 42360061 & 211,8 \\
\hline Western Sahara & 266000 & 513000 & 2,2 & 792748 & 4,0 \\
\hline Mauritania & 1030700 & 3460000 & 2,41 & 5570875 & 27,9 \\
\hline Algeria & 2381741 & 35468000 & 1,19 & 44935401 & 224,7 \\
\hline Tunisia & 163610 & 10549000 & 1,14 & 13233365 & 66,2 \\
\hline Libya & 1775500 & 6355000 & 2 & 9443196 & 47,2 \\
\hline Egypt & 1002000 & 81121000 & 1,94 & 119131300 & 595,7 \\
\hline Mali & 1240192 & 14517000 & 3,12 & 26837062 & 134,2 \\
\hline Niger & 1267000 & 15512000 & 3,63 & 31650295 & 158,3 \\
\hline Chad & 1284000 & 11227000 & 2,35 & 17865726 & 89,3 \\
\hline Sudan & 1886068 & \multirow{2}{*}{43552000} & 2,33 & \multirow{2}{*}{69034723} & 345,2 \\
\hline South Sudan & 619745 & & 2,33 & & \\
\hline Total Africa & 13375286 & 254225000 & & 380854751 & 1904 \\
\hline
\end{tabular}

Table 7: annual energy needs

for sustainable development of MENA countries (2030)

\begin{tabular}{|l|r|r|r|r|}
\hline & Area $(\mathrm{km} 2)$ & Population 2010 & Population 2030 & $\begin{array}{c}\text { annual energy needs } \\
\text { (Mtoe) 2030 }\end{array}$ \\
\hline Total Asia & 5572007 & 309130906 & 442989798 & 2212 \\
\hline Total Africa & 13375286 & 254225000 & 380854751 & 1904 \\
\hline Total MENA & 18947293 & 563355906 & 823844549 & 4116 \\
\hline & & & & \\
\hline
\end{tabular}




\subsection{Clean energy production for export to Europe countries:}

Table 8 shows calculation results of Europe countries population in 2030 and annual energy needs in 2030 (5toe/capita). It can be seen that the needed energy, of Europe countries in 2030 will be about 4632 Mtoe which amount the value of $14,7 \%$ of total MENA potential.

Table 8: annual energy needs for of Europe countries (2030)

\begin{tabular}{|c|c|c|c|c|c|c|c|}
\hline Country & $\begin{array}{l}\text { Population } \\
2012\end{array}$ & $\begin{array}{c}\text { Population } \\
2030\end{array}$ & $\begin{array}{c}\text { annual energy } \\
\text { needs (Mtoe) } \\
2030, \\
\text { (5toe/capita) }\end{array}$ & Country & $\begin{array}{l}\text { Population } \\
2012\end{array}$ & $\begin{array}{c}\text { Population } \\
2030\end{array}$ & $\begin{array}{c}\text { annual energy } \\
\text { needs (Mtoe) } \\
2030, \\
\text { (5toe/capita) }\end{array}$ \\
\hline Russie & 142517670 & 170472151 & 852,36 & Finlande & 5401267 & 6460712 & 32,30 \\
\hline Allemagne & 81843743 & 97897187 & 489,49 & Norvège & 4985870 & 5963836 & 29,82 \\
\hline France & 65327724 & 78141592 & 390,71 & Irlande & 4582769 & 5481668 & 27,41 \\
\hline Royaume-Uni & 62989551 & 75344792 & 376,72 & Géorgie & 4570934 & 5467511 & 27,34 \\
\hline Italie & 60820696 & 72750522 & 363,75 & Croatie & 4398150 & 5260836 & 26,30 \\
\hline Espagne & 46196276 & 55257559 & 276,29 & Bosnie-Herz. & 3879296 & 4640210 & 23,20 \\
\hline Ukraine & 44854055 & 53652065 & 268,26 & Moldavie & 3656843 & 4374124 & 21,87 \\
\hline Pologne & 38538447 & 46097666 & 230,49 & Lituanie & 3007758 & 3597722 & 17,99 \\
\hline Roumanie & 21355849 & 25544745 & 127,72 & Albanie & 3002859 & 3591862 & 17,96 \\
\hline Kazakhstan & 17522010 & 20958908 & 104,79 & Arménie & 2970495 & 3553150 & 17,77 \\
\hline Pays-Bas & 16730348 & 20011964 & 100,06 & Macédoine & 2059794 & 2463817 & 12,32 \\
\hline Grèce & 11290067 & 13504585 & 67,52 & Slovénie & 2055496 & 2458676 & 12,29 \\
\hline Belgique & 11094850 & 13271077 & 66,36 & Lettonie & 2041763 & 2442250 & 12,21 \\
\hline Portugal & 10541840 & 12609595 & 63,05 & Kosovo & 1836529 & 2196760 & 10,98 \\
\hline Rép. tchèque & 10505445 & 12566062 & 62,83 & Estonie & 1339662 & 1602433 & 8,01 \\
\hline Hongrie & 9957731 & 11910915 & 59,55 & Monténégro & 621240 & 743095 & 3,72 \\
\hline Biélorussie & 9643566 & 11535127 & 57,68 & Luxembourg & 524853 & 627802 & 3,14 \\
\hline Azerbaïdjan & 9493600 & 11355746 & 56,78 & Malte & 414520 & 495827 & 2,48 \\
\hline Suède & 9482855 & 11342893 & 56,71 & Islande & 319575 & 382259 & 1,91 \\
\hline Autriche & 8443018 & 10099095 & 50,50 & Andorre & 72400 & 86601 & 0,43 \\
\hline Suisse & 7954662 & 9514949 & 47,57 & Liechtenstein & 36475 & 43629 & 0,22 \\
\hline Bulgarie & 7327224 & 8764440 & 43,82 & Saint-Marin & 32140 & 38444 & 0,19 \\
\hline Serbie & 7276604 & 8703892 & 43,52 & Monaco & 30510 & 36494 & 0,18 \\
\hline Danemark & 5580516 & 6675120 & 33,38 & Vatican & 836 & 836 & 0,005 \\
\hline Slovaquie & 5404322 & 6464366 & 32,32 & TOTAL & 774534703 & 926457729 & 4632 \\
\hline
\end{tabular}

\subsection{Clean energy production for desert cultivation \& repopulation}

Area needed to produce annual energy needs for MENA countries and annual energy needs for Europe (4116 + $4632=8748$ Mtoe $)$ is $(892000+1002000=1894000$ $\mathrm{km} 2$ ). Remaining area for desert cultivation \& repopulation is $5062500 \mathrm{~km} 2$. Figure 3 shows the number of inhabitant according to used area for greening and repopulation. The calculation was based on annual energy need per capita in 2030 which amounts 5toe and the need of land per capita for agriculture, building and green space purposes which amounts 1 hectare. If all remaining area used for deserts greening and repopulation, it can accommodate more than 456 Million people.

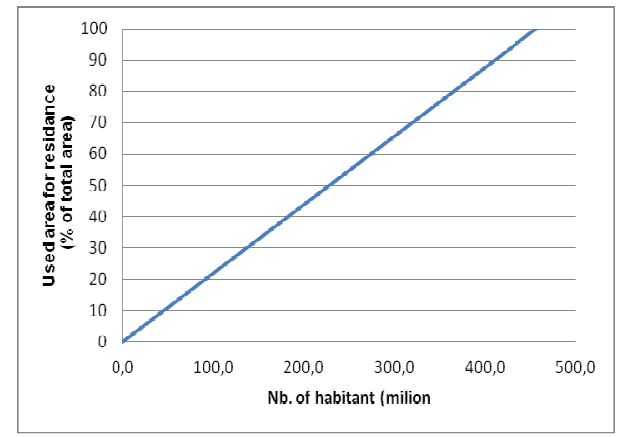

Figure 3: Number of habitant according to used area for greening and repopulation 


\section{Conclusions}

MENA has one natural resource, which so far has received scant attention, despite an abundance that has few parallels around the world: Solar Energy and Silicon, which can participate in solving the energy and climate problems for a world in a sustainable way. Calculation results allowed us to conclude that MENA solar net annual energy potential using VLS-PV with buffer plants and roads (31 538 Mtoe) is more than 2 times higher of world primary energy consumption in 2030 (15000 Mtoe).

Even a small fraction of this solar potential: $15 \%$ would already be sufficient to meet Europe countries annual energy needs in 2030, 13\% to meet MENA countries energy needs in 2030 .

Using solar energy and advance sciences will certainly achieve higher levels of economic development of a community by biological agriculture, integration of unit of desalination of briny water that would permit to irrigate thousands of hectares and solve the serious problem of treatment of waters that pollute the environment and caused the destruction of thousands of palm trees in the deserts. It will also permit to Desert cultivation and repopulation.
It is hoped that this space becomes a haven of peace for future generations. Sharing this energy should become the engine for sustainable energy guarantees a global future for all populations, the unbreakable link between the countries for a lasting world peace. At the end of oil, there will be sun and sand.

\section{References}

[1] S. Flazi, A. Boudghene Stambouli and Z. Khiat "Sahara solar potentials: energetic, socio-economic and sand reserve" 2AASE Forum and 4SSB Workshop - 15 and 16 May 2012 - USTO / ORAN

[2] S. Flazi, A. Boudghene Stambouli and Z. Khiat, "The potentials of Arabic Middle East deserts: energetic and socio-economic" GCREEDER 2013, September 10th - 12th 2013, Amman-Jordan

[3] S. Flazi, A. Boudghene Stambouli and Z. Khiat, "Sahara photovoltaic potential and silicon reserve"

3AASEF \& 5SSBWS - 6 and 8 May 2013 - Hirosaki / Japan

[4] BP Statistical Review of world Energy, June 2012.

[5] Energy from the desert, Very Large Scale PhotoVoltaic systems, earthscan publishing for a sustainable future, London Sterling, VA, 2006.

[6] Energy from the desert, Feasibility of Very Large Scale Photovoltaice Power Generation Systeme. James \& James 2003 